\title{
JAWA, JUGGERNAUT, DAN ALAM SEBAGAI TEMBANG \\ TENTANG ZIARAH TANAH JAWA
}

\author{
Tia Setiadi
}

Esais, Penerjemah dan Editor Jurnal Sajak

Email: tiasetiadi@yahoo.com

\author{
Judul Buku: Ziarah Tanah Jawa | Penulis: Iman Budhi Santosa \\ Penerbit: Intan Cendikia, Yogyakarta | Tahun Terbit: 2013 \\ Tebal: 127 HLM.
}

\section{/I/}

B iarlah saya buka pembicaraan ini dengan satu anggapan Robert Louis Stevenson perihal kata dan sajak. Dia bilang bahwa, dalam suatu cara puisi itu dekat dengan orang kebanyakan, dengan kelimun manusia di jalanan. Lantaran bahan puisi adalah kata-kata, dan kata-kata itu tak lain dialek kehidupan. Kata-kata digunakan untuk tujuan-tujuan komunikasi sehari-hari dalam bejibun urusan yang sebagian besarnya banal dan membosankan. Yang mengherankan adalah, kata-kata biasa itu mampu disulap oleh sang penyair menjadi aneka hutan lambang, simbol dan musik dalam puisi.

$\mathrm{Si}$ penyair dengan mata penanya, bagaikan sang alkemis yang mampu menyihir kenyataan menjadi jaringan semesta warnawarni yang menakjubkan dengan batu filsuf yang dimilikinya. Bila kita menerima asumsi Stevenson, maka agaknya kita punya satu teori kata dan sajak yang baru.

Akan tetapi, seusai menjelujuri kumpulan puisi Iman Budhi Santosa teranyar bertajuk Ziarah Tanah Jawa (Intan Cendekia: Yogyakarta, Maret 2013), yang merupakan himpunan puisinya dalam kurun antara 2006-2012, saya punya impresi yang bertolak belakang sama sekali dengan teori Stevenson. Coba perhatikan, ada sajak semacam ini dari Iman Budhi Santosa:

"Pagi ketika prenjak bersabutan di halaman pintu jendela jadi menanti siapa yang akan datang.
Apakah dulu benar ada benih ditabur kemudian lama ditinggalkan, serupa nama yang dikubur

tapi tak pernab hancur berpuluh tabun dilupakan.

Adakah kini sebutir biji bakal jatuh

dari parub burung pleci

tatkala berlompatan di dahan ranting pohon murbei?

Semalam ketika burung kulik dan tu'u mengharubiru, berputar-putar di atas pucuk. randu

kemudian binggap pada rumpun kembang sepatu

barangkali ia tengah mengajak cicak dan jengkerik

memagari batimu yang lelap

dari marabahaya di balik gelap dan lindap

Tengah hari ketika seekor ular lare angon menyasar ke beranda dari celah akar pohon sengon

jangan siapkan cabang bambu ori

tatap matanya, dan bisikkan lewat hati

irama tembang kinanthi

dalam liuk gemulai jemari tangan dan kaki

Menjelang senja, ketika sepasang derkuk.u

bercengkerama di bubungan rumah

katakan pada mereka, cinta tak akan punah

selama kicau merdu, lembut kata

dan kelepak rindu, meluruskan jalan menikung mengingatkan hatimu hatiku yang tak kenal manisnya madu

Lalu, ketika seekor gagak hitam menyeruak mabkota pohon salam menabrak belimbing muda, menghajar buah serikaya

jemputlab ia dengan lambaian 


\section{Jurnal Poetika Vol. 1 No. 1, Juli 2013}

\begin{abstract}
lemparkan sebongkah garam, taburkan segenggam biji asam agar bala dan petaka tenang tak bergerak. diperangkap waktu yang tak mau berhenti walau sejenak."
\end{abstract}

(Tembang Tanah Jawa, hal 88-89)

Berbeda dari asumsi Stevenson, dalam sajak di muka saya tak melihat ikhtiar penyairnya untuk menderetkan kata-kata biasa dan kemudian mengubahnya menjadi kata-kata sihir yang ajaib dan dahsyat. Lagi pula asumsi Stevenson bisa tergelincir kedalam apa yang disebut Alfred North Whitehead sebagai fallacy of the perfect dictionary: sebuah kesalahan berpikir bahwa untuk setiap persepsi indrawi, untuk setiap pernyataan, untuk setiap gagasan abstrak seorang bisa menemukan padanannya, sebuah simbol yang eksak, dalam sebuah kamus.

Padahal kenyataan bahasa-bahasa tidaklah seperti itu. Pengarang Argentina Jorge Luis Borges pernah memberi ilustrasi bahwa kata "uncanny" dalam bahasa Inggris, tak ditemukan padanannya dalam bahasa manapun, sebab orang-orang yang berbicara bahasa-bahasa tersebut mungkin memang tak membutuhkan kata tersebut. Dengan demikian bahasa bukanlah ditemukan oleh kamus, bukanlah penemuan filolog dan akademisi. Bahasa berpusar melintasi waktu, melintasi ruang, dilontarkan oleh para nelayan, petani, rentenir, para pemburu. Bahasa tidak datang dari perpustakaan, melainkan menderu dari angin, dari padang-padang, dari sungai, dari fajar dan cahaya.

Sajak Iman Budi Santoso di atas, dengan demikian, bukan menyihir kata dari material biasa, melainkan mengembalikan kata kepada muasalnya. Dalam hal Iman, muasal ini sudah spesifik: Tanah Jawa. Kata "Tembang” di judul sajak juga seperti mengisyaratkan bahwa pada mulanya sajak dan tembang di Tanah Jawa memang tak terpisahkan. Sajak adalah tembang: kisah yang dinyanyikan. Dan tembang itu, seperti sudah saya katakan: spesifik. Orang-orang Jawa secara turun temurun sudah mempunyai terjemahan dan bahasa lambang tersendiri tentang alam: ketika sepasang derkuku/ bercengkerama di bubungan rumah/katakan pada mereka, cinta tak akan punah/selama kicau merdu, lembut kata/dan kelepak rindu, meluruskan jalan menikung/mengingatkan hatimu hatiku yang tak kenal manisnya madu.

\section{$/ 11 /$}

Sajak-sajak Iman datang bukanlah untuk menyihir dan mencengangkan kita, bukan pula untuk membuat kita bergumul berpusaran dalam permainan terang dan gelapnya kata-kata, melainkan untuk menembangkan pelbagai ihwal, seperti dengan plastis dikabarkannya:

\section{"Karena wong Jawa nggone semu sinamun ing samudana,sesadone ing adu manis maka, saya tak akan memainkan gelap terang dalam puisi dan membuatmu tercengang \\ Aku hanya akan mendendangkan tembang ketika lebah kumbang datang pergi menghisap madu dengan tenang."}

\section{(Lekak-Liku Perlambang, hal. 1)}

Ketika sajak adalah tembang maka konsekwensinya ia lebih dirasa ketimbang dipikir, dan lebih didengar ketimbang dirasa. Agaknya, bagi penyair Iman Budhi Santosa, pada mulanya bukanlah berpikir atau melihat atau merasa, melainkan mendengar: lambang-lambang itu, tanda-tanda zaman itu, kata puisi itu mula-mula datang padanya bukan dalam bentuk dalil-dalil abstrak, atau emosi-emosi yang menyentuh hati atau selembar pemandangan yang menakjubkan melainkan berupa desir irama atau patahan nada atau nyanyian, yang hanya bisa disimaknya ketika sendirinya sedia mendengar dalam suasana hening bening. Maka dalam sajak-sajaknya rima dan aliterasi saling bergaung, irama berpercikan dengan kontemplasi, metafora, komparasi.

Dalam visi kepenyairan Iman, semesta ini bukanlah terutama terdiri dari benda-benda, melainkan sebuah skrip atau galaksi lambanglambang atau segugusan tanda-tanda ("tanda yang mengepak melintas", kata sang penyair). Dan semua tanda itu saling ber-patembayatan satu sama lain, saling berkorespondensi satu sama lain dalam suatu metamorfosa dan pergerakan yang 
dinamis dan tak putus-putus. Kembang sepatu adalah tanda dan biji adalah tanda yang lain. Setiap jengkal tanah adalah rumah dan dingin air berkarib dengan ranting kering dan pemantik api, seperti dilukiskannya dalam sajak di bawah ini:

\author{
"Kutemukan kalian menghalau belalang \\ mengusir burung dengan liukan tali-temali \\ jerami \\ bukan dengan pekik peperangan \\ bukan dengan ancaman pedang maupun belati \\ Sebab, di halaman masih ada rumpun kembang \\ sepatu \\ wora-wari bang, pagar dengan pelipit bambu \\ serupa tanda yang mengepak melintas \\ mengajak anak-anak belajar cerdas \\ fasib mengeja putih,merah, biru, atan kelabu \\ … \\ Kapan dan di mana pun kutemukan kalian \\ tegake berdiri memuji sejengkal tanah \\ di bawah telapak kaki,sebagai rumah sendiri \\ karena dingin air perigi terus menemani \\ hangat dijaga ranting kering dan pemantik api \\ tenteram dalam ikatan patembayatan \\ untaian mawar,kantil, kenanga, dan melati."
}

(Orang-Orang Asam Garam, hal. 114115)

Fraternity menjadi primadona dalam jagad Iman Budhi Santoso. Korespondensi dan kebertautan jaringan lambang-lambang di alam semesta menjadi model bayangan baginya untuk terwujud juga di hamparan jagad sosial, maka dia menulis begini dalam sajak "Di Pangkuan Yogya":

"Di Pangkuan Yogya, tinggi rendah menyatu hitam putih enggan berseteru setiap kaki memilib jalan sendiri lidah pun susab berucap setengah hati silang sengketa tuntas sebelum menggoda kepalan tangan, ketika mata telinga menangkap semua yang diterjemabkan $\cdots$

Saksikan juga bagaimana kerdip bintang selalu menyapa dari setiap biji mata jam ikut mati menjaga rasa aman utuh dalam perjamuan, jauh dari tergesa tak ada terlambat meraih saudara tak ada jaub tatkala jarak engkau saya banya setebal bulu roma."

(Di Pangkuan Yogya, hal. 90-91)
Surga tak ada di masa depan, kemajuan bukan sesuatu yang harus dikejar dengan tergesa dan saling menyikut-menjatuhkan. Bahkan, kemajuan pun barangkali perlu dikonsepsi ulang tatkala jam pun sudah mati, sebab bukankah hanya dengan adanya jam kita mengenal waktu kronologis di mana terpisah dengan jelas antara masa lalu, masa kini, dan masa depan? Ya, hampir seluruh sajak Iman Budhi Santosa dalam buku ini menggebyarkan visiun waktu yang berbeda sama sekali dengan waktu kronologis. Dia menawarkan kembali kepada kita visiun waktu yang siklis: masa depan ada di masa lalu dan keduanya ada di masa kini.

Yang semacam inilah mungkin yang dimaknai sebagai jiwa Jawa bagi Iman Budhi Santosa: sebuah arus yang kembali ke hulu, puisi yang dikembalikan kepada nyanyi burung kulik, prenjak, ular lare angon, derkuku dan gagak hitam, di suatu masa ketika jagad Jawa justru sedang sibuk-sibuknya mematut-matut diri berenang di arus deras sungai kemajuan dan mata pusaran modernitas. Sebuah anakronisme. Mungkin kenaifan.

\section{/111/}

Pernah George Orwell, dalam novelnya yang termahsyur 1984, menujum bahwa dunia ini akan menjadi dunia yang kian stabil dan terprediksi. Keajaiban dan kecanggihan teknologi akan membuat masyarakat semakin bisa dikendalikan dan dikontrol, tak ada gerak dan tindak yang luput dari pengawasan, seluruh manusia akan berserak menjadi onderdilonderdil kecil yang berfungsi kecil-kecil dalam sebuah mesin sosial dan ekonomi yang maha besar. Namun, rupa-rupanya dunia yang kita tinggali sekarang untuk sebahagian besarnya tak begitu tampak dan terasa seperti prediksi Orwell. Sebaliknya: semakin hari dunia kita semakin lepas kendali. Lebih tepat agaknya jikalau dikatakan bahwa saat ini kita sedang mengendarai juggernaut. mesin yang lepas kendali dengan kekuatan sangat besar yang, kita sebagai umat manusia secara kolektif bisa mengendarainya untuk beberapa saat tetapi juga terus-menerus membayang ancaman bahwa kita akan kehilangan kontrol 
dan bisa saja mesin raksasa itu menghancurkan dirinya sendiri. Juggernaut ini melabrak siapa pun yang melawannya dan meskipun sementara waktu kelihatan berjalan di jalurnya yang benar bisa saja tiba-tiba berbelok di suatu tempat secara tak terduga.

Kereta modernitas yang melaju seperti juggernaut itu mengunjukkan wajah dewa janus: ia menjelma berkah sekaligus kutukan. Di satu sisi ia telah melipatgandakan kekayaan dan kesejahteraan material, memperingan kerja manusia dengan penemuan-penemuan teknologinya, menemukan puspa ragam hal yang sebelumnya tak terbayangkan. Akan tetapi di sisi lain terjadi pula pengrusakkan alam yang massif, agresifitas dan kriminalitas di daerah urban yang kian mengerikan, pengeringan dan pembusukan sumber-sumber rohaniah manusia, dan keserakahan dan kemasakahan dan kemiskinan bagi mereka yang kalah dan terlindas juggernaut.

Berhadapan dengan semua itu, Iman Budhi Santosa mempunyai sikap, posisi, dan keberpihakan yang khas dan konsisten, seperti membayang dari sajak berikut:

\section{"Mungkin, kita tak akan pernah bertemu engkau membawa dirimu dari etalase ke etalase berburu sepatu, baju warna-warni dalam gemerlap lampu. \\ Sedangkan aku tenggelam menghuni museum tua \\ renta bersama kisah sejarah \\ diperangkap ngengat dan kutu buku \\ tak bisa mengejarmu, menjadi perlu \\ seperti iklan berita \\ dicari dan dibaca dari waktu ke waktu.}

Biarlah di luar benteng jutaan orang berlari berdesak berebut mengejar rembulan matahari Biarlah debu menghajar mereka siang malam ketika jalan makin sempit, ribuan orang menjerit

tetapi, semua terus maju, semua malu

belajar menyisir, menguak tabir kota ini dari bilir ke bulu."

(Menjaga Yogyakarta, hal. 66-67)

Terhadap mereka yang mengimani dan menikmati modernitas secara total dan utuh seluruh Iman menyatakan "tak akan pernah bertemu" sebab dia berdiam di pulau yang berbeda: ketika mereka berlari dari etalase ke etalase, si penyair malah terbenam di museum tua bersama ngengat dan buku-buku lawas. Alih-alih ikut berjejalan merawak bersama orang-orang lain mengendarai juggernaut, Iman malah seperti si aku dalam sajak Robert Frost "West Running Brook" yang berjalan jauh seorang diri menyisir ke hulu, menentang arus, menemukan sumber air kearifan tradisi yang jernih berkilauan. Dia berani menjadi seorang yang "tak penting" dan "tak diperlukan". Sikap Iman yang semacam ini konsisten dalam sajak-sajaknya, bukan hanya dalam kumpulan Ziarah Tanah Jawa ini namun juga dalam dua kumpulan puisinya yang lain yakni Dunia Semata Wayang (YOI, 1996) dan Matahari-Matahari Kecil (Grasindo, 2004).

Bukan berarti Iman tak peka akan dinamika gerak dan deru perubahan yang bergebalau di sekitarnya. Bagaimana tidak? Lihat! Bahkan Malioboro, sentrum tempat dia dan rekan-rekannya dulu berkreativitas, sebuah sangktuari bagi para seniman, di mana kegilaan, keganjilan, kekurangajaran, ide-ide majnun dan edan-edanan, imajinasi-imajinasi liar dan dahsyat bukan hanya dibiarkan melainkan dirangsang untuk bermekaran, tetapi kini, puluhan tahun kemudian, juga tak luput dilindas juggernaut. Tak mengherankan bila kita pun merasakan adanya rasa sayu, mungkin murung mungkin kehilangan, juga rasa kangen yang ditahan dan disembunyikan terhadap Malioboro tempoe doeloe dan serempak dengan itu ada terguris semacam keasingan, keterkucilan, rasa terkejut dan rasa heran yang terpendam terhadap Malioboro zaman ini seperti dengan indahnya terhampar dalam dua sajak Iman di bawah:

"Rumah kami Malioboro
Mata kami Malioboro
Hati kami Malioboro
Buku kami Malioboro
Puisi kami Malioboro
...
Di Malioboro, kami pernah menjadi bayi
pernah bertapa, sekaligus bercinta
pernah menyerupai sampah


pernah belajar mengeja

pernah tak dikenal tetangga

pernah menghitung bintang, mengikuti jejak tikus tua

membangun sarang yang nyaman

di bawah tanah kelabiran kedua

bernama Yogyakarata."

(Orang-Orang Malioboro 1969, hal. 52-53)

"Selembar daun angsana yang gugur musim ketiga

dinihari menyapa (dengan wajah kecewa)

setelah terinjak sepatu bersama semut hitam di bawahnya

yang harus mati sebelum menemukan remah berkat

yang tengah dicari atau dicuri.

"Apa yang kau tunggu di sini, laki-laki tua?"

Tapi, laki-laki beruban itu merasa tak ada siapa-siapa

di bawah sepatunya, karena dirinya hanya mondar-mandir

sambil mengunyah catatan lama

$\ldots$

Ada rasa malu ketika tak ada lagi tegur sapa bersahabat

ratusan orang memilib bidup dalam etalase

berkubang dalam haraga

dan angka-angka yang senantiasa berkbianat."

(Orang-Orang Malioboro 2009, hal. 55-56)

Perlu saya katakan di sini bahwa, meskipun ada semacam eulogia ataupun rasa sayu terhadap Malioboro tempoe doeloe yang kini hilang sudah, namun tak ada membersit langgam kemarahan. Tampak bahwa penyair kita ini sudah memiliki detachment yang wajar: ia mampu mengolah dan mengendalikan emosi-emosinya, menjaga distansi darinya, mengasahnya, memeramnya, menajamkannya, mengujinya, hingga yang berpantulan dalam sajak-sajaknya adalah taburan emosi-emosi yang matang dan visioner.
Demikian pula sikapnya terhadap khazanah pulau kearifan tradisi yang ingin dijaganya. Jauh dari kesan kolot, konservatif, majal, tertutup, atau paranoia, sebagaimana sering kita dapati pada para pembela tradisi atau agama yang fanatik dan membuta-tuli, yang biasanya juga hanya memahami apa yang ingin dibelanya pada tonjolan permukaannya saja, Iman justru sangat rileks dan terbuka, terkembang lebar ibarat lengkung langit di kampung halaman sendiri, bersahaja namun kukuh, tenang tetapi yakin, hening serta dalam, serba merangkul dan bukannya mengutuk. Di suatu masa ketika individualisme tengah bersimaharajalela, di suatu masa ketika setiap orang berlomba-lomba membangun benteng kokoh di sekitaran dirinya, Iman malah membayangkan dirinya sebagai rumah yang pintu dan jendela-jendelanya tanpa kunci, sehingga siapa pun dan mahkluk apa pun bisa masuk dengan leluasa. Menakjubkan!

"Tak perlu kunci pintu ini

juga terali besi

pada jendela dan hati.

Mengapa sembunyi

tak ada musub di luar sana

selain saudara, kicau burung

bertebaran di mana-mana

Bukankah durbaka

memandang ular kecoa

selamanya malapetaka

bujan ingin merusake

tidur anak-anak manja

mimpi mandi cahaya

Maka, terus kubuka pintu jendela

biar semut kupu-kири

mengenal buku, fasib bicara

bertegur sapa dengan seksama

menghapus gumam dendam

dari perjamuan cendekia."

(Pintu Tanpa Kunci, hal. 108-109) 


\section{/1V/}

Ada suatu sikap yang tegas, berpihak, konklusif dan konsisten dalam sajak-sajak Iman Budhi Santosa tatkala dia menampilkan Wong Cilik. Dia sendiri pernah menyatakan bahwa dirinya adalah setangkai ilalang di antara hamparan padang rumput, sehingga keberpihakannya pada Wong Cilik bukan berasal dari suatu empati yang memancar dari seorang penyair menara gading yang prihatin pada kondisi rakyat jelata yang terserak di bawahnya dan yang berbeda nasib darinya, melainkan welas asih yang bergeletar bergerak dari lubuk rasa yang senasib sepenanggungan sebagai sesama Wong Cilik. Alhasil, yang terasa oleh kita adalah gurat-gurat ketulusan dan kewajaran dan kejujuran, bukan ekspresi dan laku yang dibuat-buat.

Namun bukan hanya di alaf modern ini Wong Cilik dinistakan dan diperlakukan tak adil, sejarah berabad-abad sudah selalu menindas dan melemparkannya ke pojok yang tak berharga. Catatan sejarah hanya sarat dilambari kepahlawanan para ksatria. Keberadaan Wong Cilik tak tercatat dan hilang dari bait-bait tembang. Pengorbanannya, deraan dukacaritanya, rundungan azab dan sengsara yang harus ditanggungkannya dibiarkan raib oleh lalu waktu, tak tercatat, tak dapat tempat. Maka, sang penyair pun mengusut dan terpacak tegak mendakwa sejarah:

\section{"Kini, aku menyusuri kembali gelap terang sejarah,legenda, dan prasasti setelah terlanjur dijunjung tinggi dikaji dan dipepetri karena di tengah makam para sakti selalu ada rintih kedasih, sedih burung capung berseteru cacing jengkrik mengharu-biru melawan benar salah hikayat masa lalu}

\section{Menelisik raman-zaman tercabik mengusut lekuk-liku jalan berbalik. kutelan pabit ratapan sakit orang-orang bela pati bilang dari bait tembang yang ditulis para pujangga dengan setengah hati}

Berbekal pena dan dengan tinta air mata kugambar batu nisan mereka juga sebaris nama sederhana

berbunyi: rakyat jelata."

(Di balik Sejarah. Legenda, dan Prasasti, hal. 70-71)

Sipenyair sudah jemu menyaksikan nenek moyang dan anak-cucunya senantiasa harus berkata "ya" pada Sang Tuan dan bertanya-tanya bagaimana kalau sekali-sekali kaum punakwan itu mengatakan "tidak"?

"Sesekali, lepaskan mereka, Bandara,
istirah menerjemabkan perintab
menimbang langkah berubah arah.
Dan ketika sigap berkata tidak
jawablah ya, karena bertapa dan menjaga
sudah disaksikan pada seluruh tiang pendapa
silsilah sejarah pun lengkap dibaca:
"abdi hanya menabung mulia, bukan pondasi
harus di bawah tanah selama-lamanya."

(Sajak Punakawan, hal. 24)

Dan setelah menghambakan diri seumur hidupnya, setelah mengorbankan seluruh tenaga, pikiran, waktu dan bahkan terkadang anak gadis dan bininya sendiri itu, bila saja sekali waktu si Wong Cilik membutuhkan Tuannya, maka sang Tuan tak akan pernah ada untuknya:

"Di mana mereka? Di mana? Para raja sekarang bertabta?"

Ratusan mayat tak menjawab Ribuan mulut tsayat menyabut. Raja memang tak pernab ada Ketika ribuan orang membutubkannya."

(Gabah Den Interi, hal. 14)

Kalau sejarah menampik mencatat Wong Cilik, maka sang penyair merasa dirinyalah yang harus menuliskannya. Namun dia merasa barulah menulis paragrap satu, sampai kemudian bersua sebuah makam tanpa nama, dan menemukan bahwa itulah buku utuh yang harus dia sebut.

"Sesekali saya berjongkok di sampingmu tanpa barus berkenalan dan merasa perlu

Engkau kehabisan kerabat 
aku mencari sebuab alamat

Engkan bukn

aku baru menulis paragraph satu

Engkau lumut, saya rumput

Di sini semua patut disebut."

(Di Sebuah Makam Tanpa Nama, hal. 103)

Tak semua sajak Iman tentang Wong Cilik berisi gugatan terhadap penindasan dan perbudakan yang tak usai-usai mencambuk punggung-punggung mereka. Ada beberapa sajak yang justru menghadirkan potret-potret lain Wong Cilik, yakni sajak-sajak yang melukisbayang kedahsyatan Wong Cilik, ketegarannya yang seteguh embun, iktiar dan kerja kerasnya yang tanpa kenal lelah tanpa kenal pasrah, harga dirinya yang sekokoh pohon dan gunung, keberanian dan keperkasaannya yang mengharubiru menantang batu cadas kehidupan. Maka, bersama-sama si penyair kita pun merasa bangga, haru, dan takjub pada keteguhan "Perempuan Kabut Desa Wanayasa":

"Bersimpub pada tanah remah nenek. moyangnya

pagi ketika bukit masih mengerucut matahari di ketiak rumpun sidaguri ia pun setia membelai bawang lanang yang menjadi tambatan hati.

Berselendang sulur semangka, menuai buah tuah

yang digelar musim sepanjang lereng dan lembah yang terus member dan tersenyum ramah

Perempuanku, ingin kusembah kau karena debu dan mimpi ibu menuntun telapak kakimu

pulang menjadi kembang kampung halaman menjadi tiang pengricik rumah tua pada zaman yang manja."

\section{(Perempuan Kabut Desa Wanayasa,} hal. 86)

Kita pun menangkap kilau yang sama anggun dan agungnya saat membaca puisi "Angin Negeri Anak Gembala". Ternyata ada sesuatu yang besar dalam diri si orang kecil itu, ada sesuatu yang indah dan luhur dalam diri si jelata yang selalu didebu-dihina-dinakan sejarah itu:

"Waktu angin mati, laying-layang kembali kertas

rautan bilah bambu dan benang kehilangan napas

anak-anak gembala pun segera meneriakean nyanyian sakti

"Cempe-cempe undangna barat gedhe

Tokopahi duduh tape

Yen kurang goleka dhewe..."

Maka entah dari mana asalnya, angin pun tiba puluban layangh-layang mendaki

Seindah itu, sepatub itu

angin negeri anak gembala ini.

...

Anak-anak gembala telanjang dada

tembang, bau keringat dan tangan-tangan kecilmu

telah mengibarkan bumu Jawa

dengan cerdas, di luar sejarah emas yang perkasa karena restu berkah para raja

tak pernah singgah di ubun-ubun mereka."

(Angin Negeri Anak Gembala, hal. 6-7)

\section{/V/}

Tetapi bagaimana seandainya Jawa sudah mati?

Dua sajak bertajuk "Ziarah Tanah Jawa" dan "Ziarah Tembuni" seperti kesaksian bahwa Jawa sebetulnya sudah mati. Kata "Ziarah" itu sendiri sudah menyarankan bahwa Jawa memang sudah mati, sehingga bukan untuk dikunjungi melainkan untuk diziarahi. Betulkah? Betulkah Jawa sudah mati?

Ya, barangkali. Namun, perkenankan saya menukil satu parabel Borges yang indah bertajuk "Inferno". Dalam parabel itu dikisahkan bahwa seekor harimau sedang galau sebab seluruh hidupnya dihabiskan hanya di ruang kandang yang sempit. Dia merindukan buasnya hutan, dan harum daging rusa yang dibantu angin. Tiba-tiba terdengar suara Tuhan: "Kau akan hidup dan mati di penjara ini, sehingga seorang lelaki yang berkali-kali melihatmu tak akan melupakanmu dan akan menaruh jasad dan 
lambangmu di sebuah sajak yang punya tempat tersendiri dalam skema jagat raya. Kau mungkin menderita sebagai tawanan, namun kau akan menjadi sepatah kata dalam sajak"

Jangan-jangan Jawa seperti harimau yang tertawan itu. Jasadnya mungkin akan hidup dan mati dalam sangkar sempit. Namun seorang penyair tua telah mengambil jiwanya dan meniupkan kembali ruhnya dalam sajaksajaknya.

"Tetapi, mengapa sekarang engkau merasa jadi tamu..."

Padahal, di sana masih ada makam lelubur. Ada nisan kayu batu

ditatah dengan goresan psaya. Mereka tak pernah lupa

siapa anak cucu yang dulu nakal, suka mencuri ketela

dan membakarnya malam-malam saat bulan puasa.

Maka, seperti terbangun dari mimpi, kucabuti rumput teki

yang berakar pada dabi mereka, yang menjalar menutup nama yang pernah mendongengkan kisah Nabi,

Ramayana bingga Mababharata

Kini, dengan keringat di dabi kucium kembali tanah itu

bersama derit bambu kusembubkan penat perjalanan bersepatu

di sini engkau saya lahir, menjadi akar dan batang kayu

di sini pula ribuan dongeng berkait menjelma biduk dan perabu."

\section{(Ziarah Tembuni, hal 78-79)}

Si anak nakal telah kembali, tamu sudah menjadi tuan rumah lagi, dan yang bermimpi telah terbangun. Sajak di atas adalah momen saat Odyssius tiba di Ithaca. Dan Jawa adalah Ithaca itu bagi Iman Budi Santoso.

Akan tetapi, sebermula menapaki baitbait pertama dan kedua sajak bertajuk "Pada Suatu Hari Umanis Pagi di Pagelaran Keraton Yogyakarta" saya seperti dibawa pada kisah seorang abdi berjiwa feodal yang terlampau mengagungkan keraton dengan segala undak usuknya yang bagiku sangat menjemukan. Semula saya menduga sajak ini hanyalah eulogia dari seorang kolot yang terlampau romantik:

"Jauh dari celah gunung kampung yang tak tercatat dalam sejarah

saya datang dengan dada dan kaki telanjang. Sendiri,

napak tilas jejak pewaris Senapati; berbekal puisi.

Sebab, tinggal mereka yang bisa merawat sesanti tanah Jawa

gemah ripah lob jinawi, tata-titi-tentrem kertaraharja

menjaganya dengan pupuh dandanggula atau kinanti

bukan dengan kalimat sakti seperti dirancang negeri ini

Sampai di depan pagar besi, disambut bau karat menyengat

saya mematung, gelisah dan bayangan lewat tak terbitung.

Tak ada lagikah pasewakan agung di sini seperti ketika Sultan menitipkan melati cempaka

kerbau sapi, juga padi dan ketela, menjadi kerabat sejati

sanak kadang di bumi Jawa? Tak ada lagikah bedhaya serimpi,

atau bondhan kendhi digelar untuk menatah mengasah tutur-langkah

sehingga lentur dan indah ketika menapak. kembali esok hari?"

Pada Suatu Hari Umanis Pagi di Pagelaran Keraton Yogyakarta, hal. 92)

Saya tercengang saat menyusuri puisi ini sampai jauh. Terutama saat tiba di bait berikut ini:

"Raja bukan penunggu singgasana, Saudarsaya.

Ia ada di mana-mana. Mengalir dalam urat nadi kota desa

sesekali ikut bertani, menempa di besalen pandai besi

menuntun orang-orang buta, menjelma tongkeat kiblat lsaya lampah yang ditiru anak. сиси dan merasuk ke dalam hatimu, juga batiku. Pagelaran juga bukan lagi sebatas pendapa tua ini

tetapi, seluas tanah Jawa yang membentang di hadapanmu."

(Pada Suatu Hari Umanis Pagi di Pagelaran Keraton Yogyakarta, hal. 93) 
Raja ternyata bukan Raja yang duduk disinggasana dan haus sembah, melainkan Raja sebagai Jiwa yang menggamit kehidupan di setiap penjuru jagat. Pagelaran juga bukan sebatas panggung sempit yang dinikmati para bangsawan atau (saat ini) para turis, melainkan membentang di seantero panggung Tanah Jawa. Maka, saya keliru. Lebih tepat bila sajak ini dibaca dari akhir ke awal, dari hilir ke hulu.

Dari titik ini sajak di atas harus dibaca dengan cara yang berbeda sama sekali. Saya ingin bilang inilah sajak sufisme jawa. Bila para penyair Indonesia pernah sibuk memoles sajaksajaknya dengan istilah-istilah impor seperti gunung kaf, tajjali, buah anggur, bunga tulip untuk meyakinkan bahwa sajaknya sufistik, yang kadang kelihatan sebagai kegenitan dan keletahan yang dangkal, maka Iman Budi Santoso bergerak dari dalam budayanya sendiri, terus mendaki dari alam lahir dan lingkungan keseharian yang dikenalnya dengan akrab, lalu membubung ke kaki langit kasunyatan yang, karena otentik, menyentuh dan membebaskan.

Jagat kecil menyatu dengan jagat Besar, sahaya tak ada bedanya dengan Sultan. Inilah pula spiritualisme orang kebanyakan. Saya tercengang bahwa meskipun hampir seluruh sajak Iman budhi santosa mewedarkan spiritualisme dan Jiwa Jawa, namun tak satu pun ada nama pujangga jawa yang disebutnya. Bagi Iman, rupa-rupanya nenek moyang itu tak bernama, dan kearifan yang ditembangkannya juga berasal dari ribuan orang Jawa tanpa nama. Puisi-puisinya adalah ihtiar tak kenal lelah untuk mengembalikan kearifan itu kepada mereka. Dengan ini, Iman Budhi Santosa, dibalik sosoknya yang ringkih, pandangannya yang seperti kabut melankoli, ketenangannya yang bersahaja, kesendiriannya yang arif, adalah seorang yang radikal.

\section{Daftar Pustaka}

Borges, Jorge Luis. 1984. Seven Night. New York: New Directions Books. . 1998. Collected Fictions, diterjemahkan dari bahasa Spanyol ke bahasa Inggris oleh Andrew Hurley. USA: Penguin Books.

Frost, Robert. 1995. Collected Poems, Prose, and Plays. New York: Literary Classics of the United States.

Giddens, Anthony. 1990. The Consequences of Modernity. Cambridge: Polity Press. . 1999. Runaway World: How Globalisation is Reshaping Our Lives. London: Profile Books Ltd.

Orwell, George. 1982. Nineteen Eighty Four. Middlesex: Penguin Books.

Paz, Octavio. 1991. Children of the Mire: Modern Poetry from Romanticism to the Avant-Garde, Diterjemahkan oleh dari bahasa Spanyol ke Bahasa Inggris oleh Rachel Phillips. USA: Harvard University Press.

Santosa, Iman Budhi. 2013. Ziarah Tanah Jawa. Yogyakarta: Intan Cendikia. 